\title{
EVALUATION OF ANTI-DIARRHOEAL EFFECT OF CURCUMIN
}

\section{Physiology}

\section{Dr Anil Kumar}

\section{Dr Vijay Kumar} Roy*

\section{Dr Neetu Arora}

Associate Professor, Dept. of Physiology SHKM Govt. Medical College Nalhar, Nuh, Haryana

Associate Professor, Dept. of Physiology SGT Medical College, Hospital \& Research Institute, Gurgaon, Haryana *Corresponding Author

Associate Professor, Dept. of Anatomy SHKM Govt. Medical College Nalhar, Nuh, Haryana

\section{Dr Shashi Pandey Professor \& Head, Dept. of Physiology, TSM Medical College \& Hospital, Lucknow}

\section{ABSTRACT}

Turmeric has been used in traditional medicine as household remedy for various diseases including biliary diseases, cough, hepatic diseases, wound healing and diarrhea etc. Curcumin is the active salt present in turmeric. This study was carried out to provide scientific basis for the use of curcumin in diarrhea and to compare it with standard medicine i.e. Loperamide. The albino rats were divided into five groups of six animals in each group. Group I (control) received vehicular fluid. Group II (positive control) received standard drug for diarrhea i.e. loperamide at the dose of $2 \mathrm{mg} / \mathrm{kg}$ body weight. Group III, IV and V were administered curcumin intragastrically by the naso-gastric tube, in the dose of $500 \mathrm{mg} / \mathrm{kg}, 750 \mathrm{mg} / \mathrm{kg}$ and $1 \mathrm{gm} / \mathrm{kg}$ body weight respectively, suspended in normal saline. After one hour of above treatment, $1 \mathrm{ml}$ of castor oil was given intragastrically to all the overnight-fasted animals to induce diarrhea. Each animal was housed separately and observed for time of onset and number of diarrheal episode for 4 hours. The data was analyzed by using SPSS 11. Remarkable anti-diarrheal effect of curcumin against castor oil induced diarrhea was observed in dose dependent manner. From the present study, we can draw a conclusion that, Curcumin have significant anti-diarrheal effect. It may be used as an adjuvant for the treatment of diarrhea, and irritable bowel syndrome.

\section{KEYWORDS}

\section{Curcumin, Anti-diarrheal, Diarrhea Albino Rat}

\section{BACKGROUND}

India has a rich history of using plants for medicinal purposes. Worldwide interest in natural products as preventive and therapeutic agents has led to a greater appreciation of the rich heritage of traditional system of medicine. Turmeric (Curcuma longa L) is a medicinal plant extensively used in Ayurveda, Unani and Siddha medicine as home remedy for various diseases. Curcuma longa L, botanically related to ginger family, is perennial plant having a short stem with pyriform rhizomes. Curcumin, the main yellow bioactive component of turmeric has been shown to have a wide spectrum of biological actions. Apart from its daily use in the kitchen as condiment and spice, Turmeric has been used in allergy, cough, fever, biliary disease, liver diseases, wound healing, diarrhoea and inflammatory conditions of joints ${ }^{[1-9]}$. Curcumin is the active salt present in turmeric. However, no scientific work has been reported yet in support of the anti-diarrhoeal activity of Curcumin. Henceforth, this study was carried out to provide scientific basis for the use of curcumin in diarrhea.

\section{OBJECTIVE}

The objective of this study was to evaluate the anti-diarrheal effect of curcumin and to compare it with standard medicine i.e. Loperamide.

\section{MATERIALS AND METHODS}

This study was conducted in Dept. of Physiology of SGT Medical College, Hospital and Research Institute, Gurgaon after getting approval from Institutional Animal Ethics Committee.

\section{EXPERIMENTALANIMALS}

Albino rats of wistar strain, weighing 130-170 gm, of either sex, raised under standard laboratory conditions were obtained from Indian Veterinary Research Institute, Izat Nagar, Barellie, Uttar Pradesh. The animals were housed in polycarbonate cages of size $35 \mathrm{~cm} \times 23 \mathrm{~cm} \times$ $16 \mathrm{~cm}$. Four rats per cage were kept. The animals were fed cooked food ad libitum with free access to water. All experiments in rats were carried out in accordance with the recommendation of guidelines for care and use of laboratory animals approved by Institutional Animal Ethics Committee

\section{DRUGS}

CURCUMIN

The Curcuma longa commonly known as turmeric, a perennial herb, contain an active component known as Curcumin (diferuloyl methane), a polyphenol. Curcumin was obtained in the form of capsule containing $500 \mathrm{mg}$ of curcumin from INDSAFF, Batala. The yellowpigmented fraction of turmeric contains curcuminoids, which are chemically related to its principal ingredient, curcumin. The major curcuminoids present in turmeric are demethoxycurcumin (curcumin II), bisdemethoxy-curcumin (curcumin III), and the recently identified cyclocurcumin. The major components of commercial curcumin are curcumin I (77\%), curcumin II (17\%), and curcumin III (3\%) (12).

\section{LOPERAMIDE}

Loperamide(Imodium) was procured from open market. This medicine is used to decrease frequency of diarrhoea This drug is a medication used to treatment of a number of diarrhea. This includes diarrhea due to traveler's diarrhea, irritable bowel syndrome etc ${ }^{[10]}$.

\section{ANTIDIARRHOELSTUDY}

The albino rats were divided into five groups of six animals in each group. Group I (control) received vehicular fluid. Group II (positive control) received standard drug for diarrhea i.e. loperamide at the dose of $2 \mathrm{mg} / \mathrm{kg}$ body weight. Group III, IV and V were administered curcumin intragastrically by the naso-gastric tube, in the dose of $500 \mathrm{mg} / \mathrm{kg}, 750 \mathrm{mg} / \mathrm{kg}$ and $1 \mathrm{gm} / \mathrm{kg}$ body weight respectively, suspended in normal saline.

After one hour of above treatment, $1 \mathrm{ml}$ of castor oil was given intragastrically to all the overnight-fasted animals to induce diarrhea. Each animal was housed separately and observed for time of onset and number of diarrheal episode for 4 hours.

\section{STATISTICALANALYSIS}

The data was analyzed by using SPSS 11. The data of number of stools was expressed as mean \pm standard error of mean (SEM). One-way ANOVA test was applied followed by Dunnet's multiple comparisons. We compared the results with the control group. P values $<0.05$ were considered to be statistically significant.

\section{RESULT}

Remarkable anti-diarrheal effect of curcumin against castor oil induced diarrhea was observed in dose dependent manner.

\begin{tabular}{|l|l|l|}
\hline Treatments & $\begin{array}{l}\text { Onset of diarrhea } \\
\text { (min.) }\end{array}$ & $\begin{array}{l}\text { Total no. of } \\
\text { diarrheal episodes }\end{array}$ \\
\hline $\begin{array}{l}\text { Group I } \\
\text { ( Normal saline } 10 \mathrm{ml} \text { ) }\end{array}$ & $\mathbf{5 8} \pm \mathbf{2 . 8 9}$ & $\mathbf{3 2} \pm \mathbf{1 . 8 6}$ \\
\hline
\end{tabular}




\begin{tabular}{|l|l|l|}
\hline $\begin{array}{l}\text { Group II } \\
\text { loperamide 2mg/kg) }\end{array}$ & $162 \pm 3.10 * *$ & $3.62 \pm 1.10 * * *$ \\
\hline $\begin{array}{l}\text { Group III } \\
\text { Curcumin } 500 \mathrm{mg} / \mathrm{Kg})\end{array}$ & $118 \pm 2.68 *$ & $18 \pm 1.29 *$ \\
\hline Group IV $(750 \mathrm{mg} / \mathrm{kg})$ & $130 \pm 2.32 * *$ & $10 \pm 1.08 * *$ \\
\hline Group V $(1 \mathrm{gm} / \mathrm{kg})$ & $144 \pm 2.66 * *$ & $7 \pm 1.89 * *$ \\
\hline
\end{tabular}

$\mathrm{N}=6 * \mathrm{P}<0.05, * * \mathrm{P}<0.01, * * * \mathrm{P}<0.001$ as compared with control group

\section{DISCUSSION}

In the present study curcumin was found to have significant antidiarrhoeal effect. We in our other study found that curcumin have an inhibitory effect on intestinal motility ${ }^{[1]]}$. The decrease in intestinal motility can be related to its calcium antagonist action and inhibitionn of prostaglandin secretion. Srinivasan found that curcumin have spasmolytic activity ${ }^{[12]}$. Huang et al found that sodium curcuminate antagonized the contractions of guinea pig ileum nicotine-induced contraction on isolated guinea pig ileum ${ }^{[13]}$. Makhlouf found that contraction of all smooth muscles, including those of gastrointestinal tract, absolutely depends on the presence of $\mathrm{Ca}^{2+[14]}$. Agonists - induced contraction may be related to the release of intracellular $\mathrm{Ca} 2+$ from the sarcoplasmic stores in addition to its influx mainly through L-type $\mathrm{Ca}^{2+}$ channels from extracellular fluid. Smooth muscle contraction can be abolished by antispasmodic drugs through the inhibition of $\mathrm{Ca}^{2+}$ and its entry or release into the cell. Gilani et al found that crude extract of turmeric relaxed potassium induced contraction in isolated rabit jejunum. This relaxation was through blockage of $\mathrm{Ca}^{2+}$ influx ${ }^{[15]}$. Godfraind et al concluded that a substance which can inhibit $\mathrm{K}+$ induced contraction is considered to be a calcium channel blocker. Thus, inhibition of high $\mathrm{K}+$ induced contraction of rabbit jejunum by turmeric extract may reflect the restricted $\mathrm{Ca}^{2+}$ entry via $\mathrm{VDCs}^{[16]}$. Gnanasekar N, Perianayagam J.B., demonstrated that sodium salt of curcumin significantly inhibit castor oil induced diarrhea ${ }^{[17]}$. It is well known that castor oil produces diarrhoea due to its most active constituent recinoleic acid which causes irritation and inflammation of the intestinal mucosa. This leads to release of prostaglandins resulting in stimulation of secretion ${ }^{[18]}$. Curcumin since is known to decrease prostaglandin synthesis ${ }^{[19]}$. Hence It may be quiet possible that antidiarrhoeal activity of curcumin may be due to inhibition of prostaglandin synthesis and its calcium antagonist effect.

\section{CONCLUSION}

From the present study, we can draw a conclusion that, Curcumin have significant anti-diarrheal effect. It may be used as an adjuvant for the treatment of diarrhea, and irritable bowel syndrome. Further studies will be conducted to find out exact mechanism of its antidiarrheal effect.

\section{REFERENCES}

1. Stanly C, Bhatt A, Keng CL. A comparative study of Curcuma zedoaria and Zingiber zerumbet plantlet production using different micropropagation systems. African Journal of Biotechnology. 2010;9(28):4326.

2. Eigner D, Scholz D. Ferula asa-foetida and Curcuma longa in traditional medicinal treatment and diet in Nepal. J Ethnopharmacol 1999; 67: 1-6.

3. 2. Kuo ML, Huang TS, Lin JK. Curcumin, an antioxidant and anti-tumor promoter, induces apoptosis in human leukemia cells. Biochim Biophys Acta 1996; 1317:95-100.

4. Goel A, Boland CR, Chauhan DP. Specific inhibition of cyclooxygenase-2 (COX-2) expression by dietary curcumin in HT-human colon cancer cells. Cancer Lett 2001; 172: expression $111-118$.

5. Chandra D, Gupta SS. Antiinflammatory and antiarthritic activity of volatile oil of Curcuma longa (Haldi). Ind J Med Res 1972; 60: 138-142.

6. Lutomski J, Kedzia B, Debska W. Effect of an alcohol extract and of active ingredients from Curcuma longa on bacteria and fungi. Planta Med 1974; 26:9-19.

7. Lee CJ, Lee JH, Seok JH, Hur GM, Park YC, Seol IC et al. Effects of baicalein, berberine, curcumin and hespiridin on mucin release from airway goblet cells. Planta Med 2003;69:523-526.

8. Dasgupta SR, Sinha M, Sahana CC, Mukherjee BP. A study of the effect of an extract of Curcuma longa Linn. on experimental gastric ulcers in animals. Ind J Pharmacol 1969; 1:49-54.

9. Ruby AJ, Kuttan G, Dinesh Babu K, Rajasekharan KN, Kuttan R. Antitumor and antioxidant activity of natural curcuminoids. Cancer Lett 1995; 94: 79-83.

10. Hanauer, S. B. (Winter 2008). "The Role of Loperamide in Gastrointestinal Disorders". Reviews in Gastroenterological Disorders. 8(1): 15-20

11. Kumar A, Purwar B, Shrivastava A. Effects of curcumin on the intestinal motility of albinio rats. Indian J Physiol Pharmacol 2010; 54 (3):284-288

12. Srinivasan KR. A chromatographic study of the cucuminoids in Curcuma longa L. J Pharm Pharmacol 1953; 5: 448-457

13. Huang MT, Wang ZY, Georgiadis CA, Laskin JD, Conney AH. Inhibitory effects of curcumin on tumor initiation by enzo[a]pyrene and 7, 12- dimethylbenz[a]anthracene. Carcinogenesis 1992; 13:2183-2186.

14. Makhlouf GM, Muthy KS. Vasoactive intestinal peptide/pituitary adenylate cyclaseactivating peptide-dependent activation of membrane - bound NO synthase in smooth muscle mediated by pertussin toxin-sensitive Gil-2. J Biol Chem 1994; 269: 15977 . muscle

15. Gilani AH, Janbaz KH, Lateef A, Zaman M. Ca 2+ channel blocking activity of turmeric crude extract. Phytothrapy Researchc 1994; 8: 161-165
16. Godfraind T, Miler R, Wibo M. Calcium antagonism and calcium entry blockade. Pharmacol Rev 1986; 38:321-416

17. Gnanasekar N, Perianayagam JB. Influence of sodium curcuminate on castor oilinduced diarrhea in rats. Indian J Pharmacol 2004; 36: 177-178.

18. Gaginella TS, Stewart JJ, Olsen WA, Bass P. Action of recinoleic acid and structurally related fatty acid on the gastrointestinal tract; Effect on water and electrolyte absorption in vitro. Journal of Pharmacology and Experimental Therapeutics. 1975; 195:355-356.

19. Koeberle A, Northoff H, Werz O. Curcumin blocks prostaglandin E-2 biosynthesi through direct inhibition of the microsomal prostaglandin E-2 synthase-1 Molecular Cancer Therapeutics 2009; 8(8):2348-55 